\title{
USE OF INCINERATED SEWAGE SLUDGE ASH IN CEMENT MORTARS: CASE STUDY IN CROATIA
}

\author{
Dražen Vouk, Marijana Serdar, Aleksandra Anić Vučinić
}

Original scientific paper

In the paper an experimental research has been carried out regarding the possibility for the use of incinerated sewage sludge ash (ISSA) in the production of cement mortars with partial cement replacement. Different mixtures of cement mortar have been investigated, with comparison of its basic characteristics with and without certain amounts of added ISSA that was incinerated at the temperature of $800{ }^{\circ} \mathrm{C}$. Additionally, the influence of the additives (metakaolin and silicon dust) was also investigated with the purpose to improve the physical characteristics of mortars. Altogether 177 specimens of cement mortar were investigated, with 9 different mixtures. In this research the sewage sludge from the Zagreb wastewater treatment plant was used. Results have shown satisfying physical and mechanical characteristics of mortars with added ISSA (workability, setting time, flexural and compressive strength) which brings to conclusion that use of ISSA in production of cement mortars seems possible and justified.

Keywords: cement mortar; incineration; ISSA; sewage sludge; wastewater

Uporaba pepela dobivenog spaljivanjem mulja u proizvodnji cementnog morta: pilot projekt u Hrvatskoj

Izvorni znanstveni članak U ovom radu je provedeno istraživanje mogućnosti i opravdanosti uporabe mulja s uređaja za pročišćavanje otpadnih voda na način da se pepeo dobiven spaljivanjem mulja ugrađuje u cementni mort kao sirovina (zamjena dijela cementa). U radu su provedena ispitivanja na cementnom mortu, pri čemu su razmatrane usporedbe osnovnih svojstava mješavina morta bez dodatka pepela i s dodatkom određenih udjela pepela dobivenog spaljivanjem mulja na temperaturi $800{ }^{\circ} \mathrm{C}$. Dodatno je ispitivan i utjecaj dodatka aditiva (metakaolina i silicijske prašine), s ciljem poboljšanja fizikalnih karakteristika morta. Ukupno je proizvedeno i ispitano 177 uzoraka cementnog morta s 9 različitih mješavina. Za potrebe ovog istraživanja rabljen je mulj dobiven na uređaju za pročišćavanje otpadnih voda u Zagrebu. Dobiveni rezultati s dodatkom pepela pokazali su zadovoljavajuća svojstva što navodi na zaključak da je u pogledu ispitivanih svojstava (obradljivost, vrijeme vezivanja, čvrstoća na savijanje i tlačna čvrstoća) moguća i opravdana uporaba mulja u proizvodnji cementnog morta.

Ključne riječi: cementni mort; mulj; otpadne vode; pepeo; spaljivanje

\section{Introduction}

The by-product of any technology applied in treatment of municipal wastewater is the sludge separated from primary and secondary sedimentation tanks, etc. Existing legislation that should clearly define this problem may be described as inadequate, both as regards Croatia and the majority of EU countries, from the aspect related to water management regulation and to the aspect of waste management. At present, the Regulations on management of sludge from wastewater treatment plants are applied when sludge is used in agriculture (NN 38/08); however, the conditions prescribed by these regulations are hard to meet either by the owner of the waste (sludge) or by the user (land owner), and therefore the use of sludge in agriculture has not been fully applied in Croatia. During recent years the majority of EU countries have also shown a continuous resistance against the use of sludge in agriculture (e.g. Germany, France, etc.), and in some countries it is even banned (e.g. Switzerland). At present sewage sludge from wastewater treatment is disposed on waste disposal landfills or at the point of origin, i.e. waste water treatment plant (WWTP) location, or in some other undefined way. This approach to the problem is not in accordance with the existing legislation, and moreover it is detrimental to the environment. Establishing of the integrated system of waste management imposes the need to find an appropriate way of managing of this kind of waste in accordance with the legislation and striving to maximum utilization of valuable components contained in sludge. The Republic of Croatia, like the majority of EU countries, has not yet adopted the national strategy of final disposal of sludge from wastewater treatment plants, and the main goal is to produce minimum quantities of sludge and to dispose as little sludge as possible, in any form, on disposals of non-hazardous or hazardous waste.

According to the Regulations on methods and conditions of waste disposals (NN 117/07), disposing of sludge from 2017 on shall not be allowed, both on existing disposal areas and in waste management centers. The same document states that waste disposals will be prohibited to accept, among others: "municipal waste if the mass of the biodegradable component exceeds $35 \%$ of the total". Biologically stabilized sludge after treatment in the technological process always contains more than 35 $\%$ of biodegradable matter. Also, the document mentions the criterion for disposing on non-hazardous waste disposals the limit value for total organic carbon (TOC) defined as $5 \%$ of the mass of dry matter, and stabilized sludge contains more than $5 \%$ TOC. Obviously, with 2017 coming near and the growth of construction of new WWTP in Croatia the problem of final disposal of sludge is becoming increasingly important. The method of sludge processing in WWTP is in dependence of the final disposal, which must be taken into consideration already at the time of plant construction. In the study [1], after thorough analysis of various solutions, and taking into account the costs of environment protection, it is concluded that the acceptable concept of final processing of sludge in wastewater treatment plants of larger capacities may be incineration of sludge. However, incineration of sludge also generates by-products (slag and ash), which must also be adequately disposed in the 
final stage, in quantities that are not negligible. According to present estimates, at the global level, about 1,7 million tons of ash from incineration of sewage sludge (ISSA) are generated on the annual basis, and this figure will most probably continue to grow in future [2]. For example, a wastewater treatment plant of the capacity of 1500000 PE produces about 80000 tons of dehydrated sludge per annum (about $30 \div 35 \% \mathrm{DM}$ ), while thermal processing would produce about $16500 \mathrm{t}$ /annum of bottom ash, plus about $1500 \mathrm{t}$ /annum of flying ash.

Results of earlier research and practice of some countries in the world show that incinerated sewage sludge ash (ISSA), with respect to its characteristics and chemical composition may be used/recycled in some industries, with particular stress on the construction industry, in production of cement, concrete, bricks, ceramics, asphalt mixtures in road construction, soil improvement mixtures, and extraction of phosphorus as a limited resource on Earth $[2 \div 8,10,11,13 \div 21,23,24]$. However, the most discussed possibility is the use/recycling of ISSA in production of cement mortar and concrete. This is supported by the fact that at present concrete is the most frequently used artificial material in the world, and that most scientific research works refer to recycling in concrete industry $[2,6 \div 25,27]$.

In production of concrete elements, including cement mortar, present research indicates a large potential for substitution of some components (cement and aggregate) by ISSA. However, conditions, methods and quantities of cement and aggregate that may be substituted by ISSA depend on a number of factors, and must be separately tested for each kind of additive, also in dependence on the properties of ash. Therefore, the need arises for continuous analyses and research on sludge from various WWTP.

\section{Incineration of sludge and ISSA characteristics 2.1 Incineration of sludge}

Incineration of sludge considerably facilitates further management of the resulting by-products, first of all thanks to substantially reduced mass and volume. Thermal processing reduces the overall mass of sludge to $85 \%$. The volume is also reduced to $90 \%$, thermal processing destroys toxic organic components, minimizes unpleasant odors and facilitates further management, and there is also the possibility of power generation [22].

Sludge incineration takes place at high temperatures $\left(450 \div 1300{ }^{\circ} \mathrm{C}\right)$ in closed plants (furnaces). In order to improve the properties of ash, adding of certain chemicals or lime is possible. In incineration, sludge is transformed into final products: $\mathrm{CO}_{2}$, water and ash (bottom ash and flying ash). The incineration system consists of an incinerator and one or more devices for prevention of air pollution $[24 \div 26]$.

Several types of furnaces are used for incineration of sewage sludge. The most frequently used type is the fluidized bed furnace $[2,12,15,17,27]$. Other types include the modular incinerator [11] and the electrical muffle furnace [22].

Properties of ISSA are influenced by the temperature of incineration. This influence is reflected on the strength of materials made using ISSA, specific gravity of ISSA, water absorption, porosity, mineralogy and microstructure of ISSA.

A part of toxic substances is removed during the incineration process, and a part of heavy metals remains immobilized in primary matrices of material consisting of inert silicates [28]. Still, incineration of sludge produces considerable quantities of ISSA (primarily the bottom ash $-90 \%$, but also flying ash $-10 \%$ ) that require further management. Possibilities of further use of ISSA are related mainly to mono-incinerators that process only sewage sludge (without adding of other municipal waste or possibly coal to improve combustion).

After incineration of sludge at high temperatures, the major components in ISSA from the fire-box are $\mathrm{SiO}_{2}$, $\mathrm{CaO}, \mathrm{Al}_{2} \mathrm{O}_{3}$ and $\mathrm{Fe}_{2} \mathrm{O}_{3}$, and these compounds are also usual in ordinary Portland cement [29, 30]. Thus, ISSA may potentially be used in concrete or mortar, partly substituting Portland cement $[10,11,19]$.

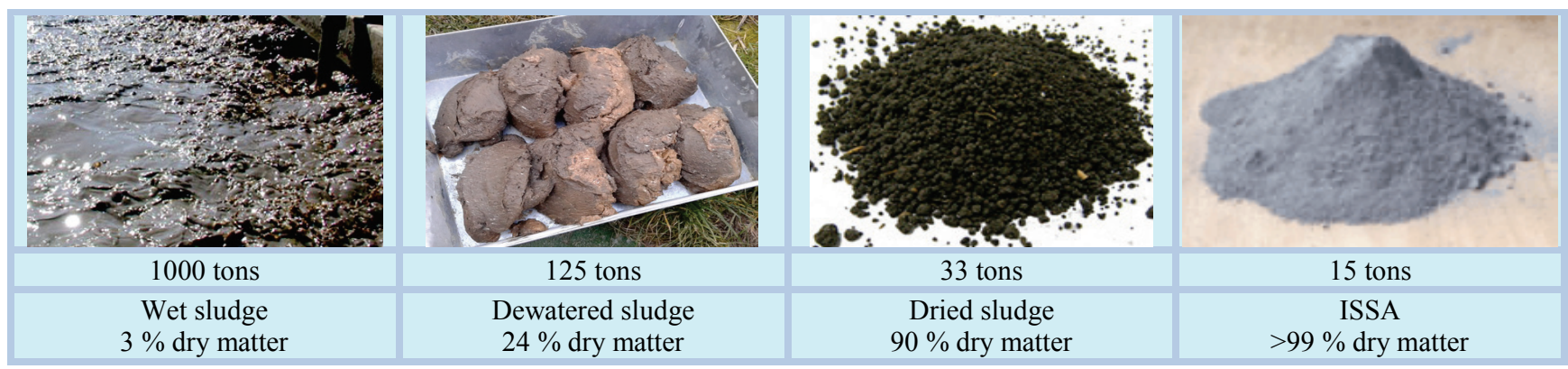

Figure 1 Characteristics of certain forms of sludge in relation to degree of processing

Increasing of incineration temperature decreases the mass of resulting ash due to additional oxidation of organic matter, leading to increased density (specific gravity) which reaches maximum values at about 1000 ${ }^{\circ} \mathrm{C}$. When the temperature of incineration is increased from 800 to $900{ }^{\circ} \mathrm{C}$, water absorption by ISSA is reduced, and above $1000{ }^{\circ} \mathrm{C}$ water absorption drops considerably (absorption at $1000^{\circ} \mathrm{C}$ is lower than $0,3 \%$ ).
The strength of the resulting concrete (dependent on porosity, specific gravity, water absorption, pore size and mineral content of ISSA) also varies with temperature changes: increased temperature leads to increased strength (between 900 and $1000{ }^{\circ} \mathrm{C}$ strength is considerably increased) [20, 31].

Sludge incineration temperature has a significant influence on the microstructure and pozzolanic properties of the resulting ISSA. At temperatures above $900 \div 950$ 
${ }^{\circ} \mathrm{C}$, depending on the sources, formation of clinker occurs, i.e. increasing of crystallization and weakening of pozzolanic properties of ISSA [22, 32].

Tantawy et al. [22] concluded that optimum temperature from the standpoint of conservation of pozzolanic properties of ISSA was about $800{ }^{\circ} \mathrm{C}$. However, depending on the sludge characteristics that differ from one WWTP to another, further investigations are recommended for the purpose of determining of optimum temperature of sludge incineration.

\subsection{ISSA characteristics}

After incineration of sludge at high temperatures, the main components in the resulting ISSA, in the form of bottom ash, are $\mathrm{SiO}_{2}, \mathrm{CaO}, \mathrm{Al}_{2} \mathrm{O}_{3}$ and $\mathrm{Fe}_{2} \mathrm{O}_{3}$, and these compounds are usually present in the ordinary Portland cement [29, 30], which opens the possibility of using ISSA in cement mortar and concrete partially substituting Portland cement $[10,11,19]$.

Medium size of ash particles ranges from 8 to 263 $\mu \mathrm{m}$, with particles up to approximately $700 \mu \mathrm{m}$. More precisely, the range of particle sizes depends on the composition of wastewater and technology of treatment and sludge processing [2].

Table 1Average values of percentages of separate oxides in ISSA based on previous research and results carried out within investigations referred to in this paper $[4,6,11,12,15,17,21,22,32,55,56,33]$

\begin{tabular}{|c|c|c|c|c|}
\hline \multirow{2}{*}{ Oxide } & \multicolumn{4}{|c|}{ Oxide percentage in ISSA / \% } \\
\cline { 2 - 5 } & Average & Zagreb $*$ & Zagreb ** & Zagreb *** \\
\hline $\mathrm{CaO}$ & 16,74 & 52,23 & 49,81 & 39,18 \\
\hline $\mathrm{SiO}$ & 33,13 & 16,21 & 19,15 & 22,12 \\
\hline $\mathrm{Al}_{2} \mathrm{O}_{3}$ & 12,43 & 7,97 & 8,63 & 10,83 \\
\hline $\mathrm{Fe}_{2} \mathrm{O}_{3}$ & 11,47 & 4,32 & 4,56 & 5,99 \\
\hline $\mathrm{MgO}$ & 2,17 & 3,16 & 2,98 & 3,45 \\
\hline $\mathrm{TiO}_{2}$ & 0,65 & 0,75 & 0,97 & 0,93 \\
\hline $\mathrm{Na}_{2} \mathrm{O}$ & 0,73 & 0,22 & 0,12 & 0,21 \\
\hline $\mathrm{K}_{2} \mathrm{O}$ & 1,29 & 0,78 & 0,36 & 0,54 \\
\hline $\mathrm{SO}_{3}$ & 5,74 & 2,16 & 2,23 & 3,22 \\
\hline $\mathrm{P}_{2} \mathrm{O}_{5}$ & 10,70 & 7,10 & 5,21 & 7,54 \\
\hline
\end{tabular}

Note: *Results of chemical analysis of ISSA generated by incineration of fresh sludge from WWTP Zagreb/Croatia (temperature of incineration $800^{\circ} \mathrm{C}$ ) used in experimental research the results of which are presented in this paper. ** Results of chemical analysis of ISSA generated by incineration of 6 months old sludge from WWTP Zagreb/Croatia (temperature of incineration $800{ }^{\circ} \mathrm{C}$ ). ${ }^{* * *}$ Results of chemical analysis of ISSA generated by incineration of 12 months old sludge from WWTP Zagreb/Croatia (temperature of incineration $800^{\circ} \mathrm{C}$ ).

The characteristics and chemical composition of ISSA depend to a considerable extent on the characteristics of wastewater and sludge generated in the wastewater treatment process [2]. ISSA characteristics may vary a great deal even in plants operating in similar conditions $[11,54]$. All this underlines the importance of further investigations of use of sludge/ash from various WWTP.

For better insight into the variety of ISSA characteristics, Table 1 shows average values of separate chemical compounds (oxides) in ash, resulting from incineration of sludge from various WWTP in the world. Additionally, for comparison, corresponding values of these oxides are given, resulting from incineration of sludges of different age from WWTP Zagreb (Croatia).

\section{Use of ISSA in production of cement mortar}

ISSA may be used in production of cement mortar either as pozzolanic active material, partly substituting cement, or as inert filling substituting sand.

Technical criteria for evaluation of influences of using ISSA in production of cement mortar are usually based on analyses of its physical properties (workability, setting time, gas permeability) and mechanical characteristics (compressive strength, flexural strength), while ecological effects are analyzed by monitoring of leaching of separate chemical elements and compounds from the resulting materials.

Partial substitution of Portland cement by ISSA influences the workability and strength development of cement mortar $[2,11,12,15,17,19]$.Using of ash as a substitute for a part of cement results in higher requirements for water, with simultaneous reduction of workability quality and longer setting time. Reduction of mortar workability, even at lower ratios of cement substitution by ISSA, is caused by irregular morphology of ISSA particles. According to some authors, poor workability may be compensated by increasing of fineness of ash particles [11], adding of mineral additives (superplasticizers) [12], or by adding of flying coal ash into the mixture [56]. Pan et al. [11] concluded that increased fineness of ash particles improves workability of the mortar, with longer setting time, higher absorption of water (due to larger free area of particles), pozzolanic activity is also increased, leading to higher compressive strength of the mortar.

Increasing the ISSA portion showed the decrease of compressive strength of the mortar, while increased fineness of ISSA particles contributed to increasing of mortar strength, with the same portion of ISSA. Cyr et al. [15] indicates that adverse effect of adding of ISSA on early strengths of mortar in later phases of setting loses importance (adverse effect on strength after 28 days is considerably reduced in relation to strength after 7 days).

According to Chen et al. [23] mortar strength (compressive and flexural) drops linearly with increasing of the portion of ISSA substituting cement. This effect is explained by two hypotheses: too much water required in mixtures with ash in order to maintain workability and $\mathrm{CaO}$ content in ISSA (less than $10 \%$ ) that affect the hydraulic properties. For the type of ISSA used in their research, Chen et al. [23] concluded that the optimum portions of cement substitution in production of mortar with ISSA are $10 \%$.

Monzo et al. $[7 \div 9]$ recorded moderate increase of compressive strength of mortars with ISSA content in relation to reference samples. They showed average growth of strength of 8,3 to $15,3 \%$ in cases when $15 \%$ of cement were replaced by ISSA. These samples were cured by immersion in water at $40 \%$, and this moderately increased temperature of curing is considered the reason of the recorded results.

The ecological effect of ISSA into mortar has been discusses by several authors. Investigations done so far used the leaching tests to determine the concentration of heavy metals in incinerated sewage sludge ash. The results show that in leaching of heavy metals from ISSA most frequently molybdenum (Mo) and selenium (Se) 
appear in concentrations higher than allowed, while the leaching test of cement mortars showed that no chemical element appeared within limits higher than permitted for classifying of mortar into the "non-hazardous waste" category $[2,23]$.

Comparing of results by different authors shows considerable differences in absolute values and in the trends of the results of compressive strength [6, 11, 29]. Obvious differences according to various authors are, first of all, the consequence of different composition of mortars and concrete, mainly different water and cement ratios. However, other important factors are obviously the incineration process, type of furnace, temperature, the influence of various additives during incineration, etc., which are all leading to a different microstructural composition of obtained ISSA. Reviewing of the state of knowledge in the field of research leads to the conclusion that the influence of the applied incineration procedure on physical and chemical properties of ISSA and the technology of preparation and processing of mortar have not been thoroughly investigated, and there is still a large space for further research.

\section{Experimental research 4.2 General}

This paper presents experimental research carried out with the aim of investigating the effect of incorporating of ISSA (bottom ash) obtained from WWTP Zagreb on the properties of cement mortar in fresh and solid condition,

Fresh stabilized and dehydrated sludge was collected at WWTP Zagreb (with second stage of treatment with application of conventional process with activated sludge and subsequent anaerobic sludge stabilization), and transported to the laboratory where it was subjected to drying at the temperature of $105^{\circ} \mathrm{C}$, for 24 hours. After drying, sludge was incinerated in the laboratory furnace at $800^{\circ} \mathrm{C}$, for 3 to 5 hours.

The resulting samples of ISSA were handed over to a laboratory for silicate analysis in order to obtain chemical composition of ash. The results of analysis of ash used for the purpose of this research are shown in Tab. 1 (third column).

Table 2 Composition of reference mixture of mortar

\begin{tabular}{|l|c|c|c|}
\hline \multicolumn{1}{|c|}{ Material } & Mass $(\mathrm{kg})$ & Density $\left(\mathrm{kg} / \mathrm{dm}^{3}\right)$ & Volume $\left(\mathrm{dm}^{3}\right)$ \\
\hline Cement & 0,61 & 3 & 0,20 \\
\hline Water & 0,305 & 1 & 0,31 \\
\hline Air & 0 & 0 & 0,03 \\
\hline $\begin{array}{l}\text { Aggregate } \\
(0 \div 4 \mathrm{~mm})\end{array}$ & 1,83 & 2,75 & 0,67 \\
\hline Total & 2,75 & 2,28 & 1,20 \\
\hline
\end{tabular}

Nine different mixtures of cement mortar were prepared for the purpose of this research -2 reference mixtures (M1 with CEM II 42.5 and M7 with CEM III 32.5; without adding of ISSA) and 7 mixtures in which a part of cement was substituted by ISSA in percentages 10 $\%, 20 \%, 30 \%$ and $40 \%$ (M2-M6 with CEM II 42.5 and M8-M9 with CEM III 32.5). In some mixes additional to ISSA other mineral additives (metakaolin and silica fume) in the percentage of $5 \%$ were added. All mixtures were prepared with the same water-cement ratio $\mathrm{w} / \mathrm{c}=0,5$.
Tab. 2 shows the composition of the representative mortar mixture regardless of whether CEM II 42.5 or CEM III 32.5 was used.

\subsection{Test methods}

During research physical and mechanical characteristics of the 9 mixtures were analyzed. The analyses included the following properties:

Workability - in order to determine the quality of the mixture with added ISSA and to analyze the influence of ISSA in combination with other mineral additives on workability of concrete. Workability of fresh mortar was determined by means of the flow table, in accordance with the standard HRN EN 1015-3:1999. Workability tests were carried out on two samples for each mixture, and the mean value was considered relevant.

- Setting time - in order to determine the quality of mixture containing ISSA and to analyze the influence of ISSA in combination with other mineral additives on the hydration process. Setting time tests were carried by the method of needle penetration on the Vicat apparatus, in accordance with the standard HRN EN 196-3:2003. The tests included the initial and the final setting time.

- Flexural strength and compressive strength - in order to evaluate mechanical properties of mixture containing ISSA and to determine the influence of ISSA in combination with other mineral additives on the increase of mortar strength. Testing of mortar flexural strength was carried out on prisms $40 \times 40 \times$ $160 \mathrm{~mm}$, in accordance with the standard HRN EN 196-1:2003. Compressive strength of mortar was tested on halves of samples previously used to test flexural strength, each half of the broken sample being separately tested for compressive strength, in accordance with the standard HRN EN 196-1:2003

\subsection{Analysis of results}

Summarized results of tests of physical properties of cement mortars (workability and setting time) are shown in Tab. 3 and explained in more detail in Sections 4.3.1 and 4.3.2, respectively. Results of tests of mechanical properties of cement mortars are given in Sections 4.3.3 (Flexural strength), and 4.3.4 (Compressive strength).

\subsubsection{Workability}

Results of workability tests on nine mixtures of cement mortars are shown in Tab. 3, and graphically in Fig. 2.

The results have shown that increasing of the ISSA portion causes reduction of mortar workability. Substitution of cement CEM II 42.5 by ISSA in $10 \%$ portion resulted in workability of $140 \mathrm{~mm}$, in relation to the reference mixture with $172 \mathrm{~mm}$, which is a loss of workability by $19 \%$.

Adding of $5 \%$ of metakaolin to the mixture with 10 $\%$ of ISSA resulted in consistency of $137 \mathrm{~mm}$, which is the reduction by $21 \%$ in relation to the reference mixture and $2 \%$ in relation to the mixture with $10 \%$ of ISSA. The possible conclusion is that the influence of metakaolin on 
the loss of workability is insignificant. If the results are compared with those obtained by Garces et al. [17], who substituting cement CEM I 52.5 by $10 \%$ of ISSA got the loss of workability by $8 \%$, it may be concluded that the influence of tested ISSA on mortar workability is more significant than shown by the data in literature.

Table 3 Physical characteristics of tested mortar mixtures

\begin{tabular}{|c|c|c|c|c|c|c|c|}
\hline \multirow{2}{*}{ Mixture } & \multirow{2}{*}{ ISSA $(\%)$} & \multirow{2}{*}{ Metakaolin (\%) } & \multirow{2}{*}{ Silica fume $(\%)$} & \multicolumn{2}{|c|}{ Workability } & \multicolumn{2}{|c|}{ Setting time (minutes) } \\
\hline & & & & $\mathrm{mm}$ & descr. & inital & final \\
\hline M1 & 0 & 0 & 0 & 172,0 & Plastic & 65 & 125 \\
\hline M2 & 10 & 0 & 0 & 140,0 & Plastic & 62 & 120 \\
\hline M3 & 10 & 5 & 0 & 137,0 & Solid & 50 & 107 \\
\hline M4 & 20 & 10 & 0 & 110,0 & Solid & 45 & 80 \\
\hline M5 & 20 & 0 & 10 & 112,0 & Solid & 30 & 85 \\
\hline M6 & 40 & 5 & 0 & 95,0 & Solid & 150 & 350 \\
\hline M7 & 0 & 0 & 0 & 185,0 & Plastic & 95 & 135 \\
\hline M8 & 20 & 5 & 0 & 125,0 & Solid & 60 & 100 \\
\hline M9 & 30 & 5 & 0 & 95,0 & Solid & 180 & 420 \\
\hline
\end{tabular}



Figure 2 Influence of ISSA and additives on workability of cement mortar

\subsubsection{Setting time}

The results of setting time tests are shown in Tab. 3 and graphically in Fig. 3.



Figure 3 Influence of ISSA and additives on initial and final setting

The results of tests show that increasing of the portion of ISSA in mortar from 0 to $20 \%$ substitution of both cement CEM II 42.5 and CEM III 32.5 reduces the setting time. Reduced time of setting appears as the consequence of the loss of water absorbed by ISSA. Irregular morphology of ISSA and porosity cause increased water requirements, evident from the lower obtained workability, which in turn result with decrease of setting time. However, with higher amount of ISSA added (30 or $40 \%$ as substitution of cement), this influence is reversed and there is a significant retardation of setting. The reason of increased setting time is lower pozzolanic activity of ISSA in relation to cement. Cyr et al. [15] got the final setting time for mortar with $50 \%$ of ISSA increased by 3 hours (total setting time 6 hours), for mortar with $25 \%$ of ISSA by 1 hour and 30 minutes (total setting time 4 hours and 30 minutes) in relation to mortar with $0 \%$ of ISSA. The potential cause may be attributed to increased portion of heavy metals which adversely affect pozzolanic activity of ISSA.

\subsubsection{Flexural strength}

Flexural strength tests were carried out at mortar age 1, 7 and 28 days. Tab. 4 and Fig. 6 show summary results for all nine test mixtures.

The results have shown that ISSA has a favorable effect on flexural strength, if added up to $20 \%$ of cement substitution, while in mixtures with higher amount of ISSA reduction of flexural strength was noticed.

Mixture M2 with $10 \%$ ISSA and cement CEM II 42.5 has slightly higher flexural strength $(3,30 \mathrm{MPa})$ after the first day, compared to the reference mixture M1 (3.27 $\mathrm{MPa})$, probably influenced by the initial higher water absorption by ISSA. After 7 days the mixture with $10 \%$ ISSA and cement CEM II 42.5 has lower flexural strength in relation to the reference mixture, by $5 \%$. Also, lowering of flexural strength by $8 \%$ was noticed after 28 days. If this is compared with results obtained by Garces et al. [17] and Jamshidi et al. [19], it may be noticed that the results are similar. It may be concluded that with adding of $10 \%$ of ISSA reduction of flexural strength is insignificant.

Mixture M3 with cement CEM II 42.5, with $10 \%$ of ISSA and $5 \%$ of metakaolin after 1 day had flexural strength of 3,13 , which is a reduction of $4 \%$ in relation to the reference mixture, and by $5 \%$ in relation to the mixture (M2) with $10 \%$ Of ISSA. After 28 days a reduction of the difference between flexural strengths of the mixture M3 and the reference mixture M1 was noticed. Thus, the flexural strength of the mixture M3 was lower by $0,06 \%$ in relation to M1. It may be concluded that $5 \%$ of metakaolin mixed with ISSA has a favorable effect on flexural strength, and the differences in relation to the reference mixture are negligible. 
Mixture M4 with cement CEM II 42.5, with $20 \%$ of ISSA and $10 \%$ of metakaolin achieved the best results regarding flexural strength in relation to all other mixtures with cement CEM II 42.5. After one day flexural strength of M4 was $7 \%$ lower in relation to the reference mixture M1. After 7 days, the difference between flexural strengths of M4 and M1 was reduced to $3 \%$, while after 28 days measured flexural strength of M4 was 9,05 MPa, which is the increase of flexural strength of $20 \%$ in relation to the reference mixture. It may be concluded that the mixture M4 has the best ratio of ISSA and metakaolin that very favorably affects the flexural strength of mortar.

Mixture M5 with cement CEM II 42.5, with $20 \%$ of ISSA and $10 \%$ of silicon dust after 1 and 7 days has lower flexural strength in relation to the reference mixture M1, by $21 \%$ and $17 \%$, respectively. After 28 days mixture M5 and the reference mixture M1 have the same flexural strength. It can be concluded that addition of silica fume also has a favorable influence and that it cancels out decrease of strength caused by higher addition of ISSA.

Table 4 Flexural strength of tested mortar mixtures

\begin{tabular}{|c|c|c|c|c|c|c|}
\hline \multirow{3}{*}{ Mixture } & \multirow{3}{*}{$\begin{array}{l}\text { ISSA } \\
(\%)\end{array}$} & \multirow{3}{*}{$\begin{array}{c}\text { Metakaolin } \\
(\%)\end{array}$} & \multirow{3}{*}{$\begin{array}{l}\text { Silica } \\
\text { fume } \\
(\%)\end{array}$} & \multirow{2}{*}{\multicolumn{3}{|c|}{$\begin{array}{l}\text { Flexural strength } \\
(\mathrm{MPa})\end{array}$}} \\
\hline & & & & & & \\
\hline & & & & 1 & 7 & 28 \\
\hline M1 & 0 & 0 & 0 & 3,27 & 6,69 & 7,23 \\
\hline M2 & 10 & 0 & 0 & 3,30 & 6,36 & 6,86 \\
\hline M3 & 10 & 5 & 0 & 3,13 & 6,23 & 7,35 \\
\hline M4 & 20 & 10 & 0 & 3,04 & 6,52 & 9,21 \\
\hline M5 & 20 & 0 & 10 & 2,58 & 5,58 & 7,25 \\
\hline M6 & 40 & 5 & 0 & 1,20 & 1,95 & 4,76 \\
\hline M7 & 0 & 0 & 0 & 1,59 & 6,28 & 9,75 \\
\hline M8 & 20 & 5 & 0 & 1,79 & 6,96 & 10,01 \\
\hline M9 & 30 & 5 & 0 & 1,54 & 4,96 & 5,32 \\
\hline
\end{tabular}

Comparing the mixture M5 with M4 prepared using cement CEM II 42.5 , with $20 \%$ of ISSA and $10 \%$ of metakaolin, one may see that the mixture M4 achieves 20 $\%$ higher flexural strength. It may be concluded from the above that metakaolin has better pozzolanic activity than silica fume and shows better compatibility with ISSA.

Mixture M6 with cement CEM II 42.5, with $40 \%$ of ISSA and $5 \%$ of metakaolin after 1 day had flexural strength by $63,4 \%$ lower in relation to referent mixture M1. After 7 days the mixture M6 had flexural strength $70,8 \%$ lower in relation to reference mixture. Also, after 28 days flexural strength lower by $55 \%$ than the reference mixture was noticed. The reason of considerable reduction of flexural strength of M6 may be attributed to reduced pozzolanic activity of ISSA in relation to cement which becomes more pronounced at larger quantities of ISSA. Also "dry segregation" of M6 mixture was noticed due to great reduction of workability. Segregation caused less connected texture of cement mortar, with "shelling" of aggregate particles in solid state, which finally resulted in lower flexural strengths in relation to reference mixture. Adding of larger quantities of ISSA to mortar requires further investigations with the use of superplastifiers as a possible solution for reduced workability and segregation which might finally result in smaller differences of flexural strength between experimental and reference mixtures.
In addition to M4, excellent results have been achieved with M8 prepared with cement CEM III 32.5, with $20 \%$ of ISSA and $5 \%$ of metakaolin which has higher flexural strength after 1 and 7 days in relation to the reference mixture M7 prepared with $100 \%$ of cement CEM III 32.5. After 1 day flexural strength of M8 was by $12,5 \%$ higher in relation to the reference mixture $\mathrm{M} 7$, and after 7 days $11 \%$ higher flexural strength in relation to M7 was recorded. It may also be concluded regarding M8 that it resulted in comparatively high flexural strengths.

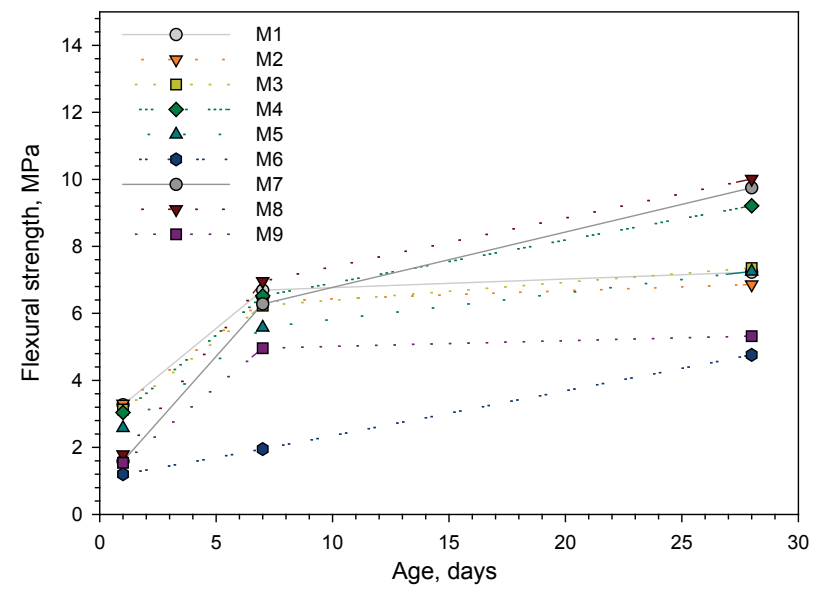

Figure 4 Influence of ISSA and additives on flexural strength of cement mortar

Mixture M9 with cement CEM III 32.5, with $30 \%$ of ISSA and $5 \%$ of metakaolin after 1 and 7 days had lower flexural strength by $14 \%$ and $21 \%$, respectively in relation to reference mixture M7 with $100 \%$ of cement. Also, lower flexural strength was noticed after 28 days as well. The reason of poor results is the same as with M6, which is attributed to considerable decrease of workability, lower pozzolanic activity of ISSA in comparison with cement, and segregation.

\subsubsection{Compressive strength}

Compressive strength tests were performed at mortar age $1,3,7,14,28$ and 78 day. Summary results for all nine test mixtures are shown in Tab. 5 and Fig. 7 ,

Mixture M2 with 10\% ISSA and cement CEM II 42.5 after 1 day had compressive strength reduced by $7 \%$ in relation to the reference mixture M1 prepared with $100 \%$ of cement, while after 3 and 7 days reduction of compressive strength was $3,5 \%$. After 21 days, minimum difference between M2 and reference mixture was noticed, M2 having the compressive strength only $1 \%$ lower. Comparing of results for M2 and M1 with results by Garces et al. [17] it becomes visible that the results are rather close, and in this research the influence of $10 \%$ of ISSA on compressive strength after 28 days may be completely ignored, because the difference is $1 \%$. After 78 days, mixture M2 had a compressive strength lower by $7,4 \%$ in relation to $\mathrm{M} 1$, which is similar to results by Jamshidi et al.[19] with $10 \%$ reduction of compressive strength.

Mixture M3 with cement CEM II 42.5, $10 \%$ ISSA and $5 \%$ metakaolin after 1 day has compressive strength lower by $18 \%$ in relation to reference mixture M1. After the third day, higher compressive strength was recorded 
in $\mathrm{M} 3$ in relation to $\mathrm{M} 1$, while after 28 days compressive strength of M3 was $12 \%$ higher in relation to reference mixture M1.

Comparing the mixtures M3 and M2, it may be concluded that compressive strength of M3 after 28 days is higher by $13 \%$. The results lead to the conclusion that matakaolin mixed with ISSA has a favorable effect on compressive strength. After 78 days, mixture M3 has 4\% higher compressive strength in relation to M1. Mixture M3 has achieved the highest compressive strength in relation to all mixtures prepared with cement CEM II 42.5 .

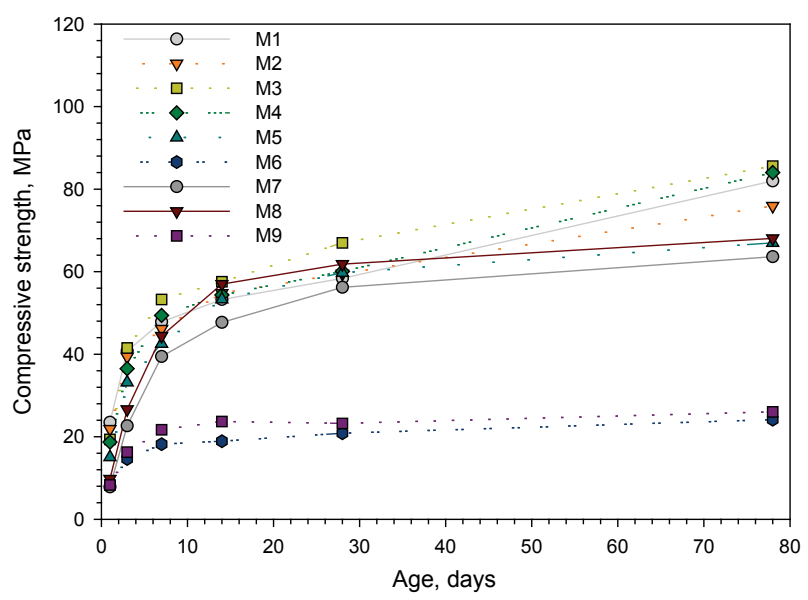

Figure 5 Influence of ISSA and additives on compressive strength of cement mortar

Mixture M5 with cement CEM II 42.5, $20 \%$ ISSA and $10 \%$ silicon dust has lower compressive strength after 1 and 3 days, by $36 \%$ and $19 \%$, respectively, in relation to reference mixture M1. After 28 days, mixture M5 has compressive strength $1 \%$ higher in relation to M1. After 78 days compressive strength of M5 is $18 \%$ lower in relation to M1. It may be concluded that mixture M5 with silicon dust has poorer results in comparison with mixture M4 with metakaolin and ISSA. The reason is the difference of pozzolanic activity between metakaolin and silicon dust.

Mixture M6 with cement CEM II 42.5, with $40 \%$ ISSA and $5 \%$ metakaolin after 1 and 3 days had lower compressive strength by $65 \%$ and $61 \%$, respectively. Also, after 28 days compressive strength of M6 lower by $65 \%$ was recorded, in relation to reference mixture M1.

If mixture M8 prepared with cement CEM III 32.5, $20 \%$ ISSA and $5 \%$ metakaolin is compared with reference mixture M7 with $100 \%$ cement, higher compressive strengths are noticed from 1 to 14 days. The increase of compressive strength of M8 after 1 day in relation to M7 is $24 \%$, and after 14 days increasing of compressive strength by $19 \%$ was noticed. After 78 days compressive strength of M8 is 7,2 \% higher in relation to M7. Mixture M8 has shown markedly favorable results as regards compressive strength.

Mixture M9 with cement CEM III 32.5, with $30 \%$ ISSA and $5 \%$ metakaolin after 1 day had compressive strength $6 \%$ higher in relation to reference mixture M6, while after 3 days compressive strength was $29 \%$ lower. Also, lower compressive strength by $50 \%$ of mixture M9 was recorded after 28 days.

Table 5 Compressive strength of tested mortar mixtures

\begin{tabular}{|c|c|c|c|c|c|c|c|c|c|}
\hline \multirow{2}{*}{ Mixture } & \multirow{2}{*}{$\begin{array}{c}\text { ISSA } \\
(\%)\end{array}$} & \multirow{2}{*}{$\begin{array}{c}\text { Metakaolin } \\
(\%)\end{array}$} & \multirow{2}{*}{$\begin{array}{c}\text { Silica fume } \\
(\%)\end{array}$} & & \multicolumn{5}{|c|}{ Compressive strength (MPa) } \\
\cline { 5 - 10 } & & & & 1 & 3 & 7 & 14 & 28 & 78 \\
\hline M1 & 0 & 0 & 0 & 23,48 & 40,76 & 47,84 & 53,25 & 58,39 & 81,98 \\
\hline M2 & 10 & 0 & 0 & 21,85 & 39,37 & 46,13 & 54,78 & 59,49 & 75,92 \\
\hline M3 & 10 & 5 & 0 & 19,34 & 41,52 & 53,26 & 57,55 & 66,99 & 85,57 \\
\hline M4 & 20 & 10 & 0 & 18,72 & 36,50 & 49,41 & 54,34 & 60,07 & 84,00 \\
\hline M5 & 20 & 0 & 10 & 15,07 & 33,16 & 42,54 & 53,31 & 59,72 & 66,97 \\
\hline M6 & 40 & 5 & 0 & 8,52 & 14,63 & 18,21 & 18,91 & 20,86 & 24,13 \\
\hline M7 & 0 & 0 & 0 & 7,83 & 22,63 & 39,45 & 47,71 & 56,22 & 63,61 \\
\hline M8 & 20 & 5 & 0 & 9,77 & 26,63 & 44,42 & 56,98 & 61,83 & 68,06 \\
\hline M9 & 30 & 5 & 0 & 8,33 & 16,27 & 21,68 & 23,69 & 23,23 & 26,04 \\
\hline
\end{tabular}

\section{Conclusion}

The use of ISSA in production of cement mortar, with ISSA substituting a part of cement, resulted in satisfactory physical and mechanical properties of mortar. Investigations showed that adding of ISSA to cement mortar had certain adverse effect on properties of mortar in fresh condition. Increasing of the portion of ISSA reduces mortar workability and setting time. The influence of ISSA has proven favorable, as some mixtures exhibited better mechanical properties in relation to reference mixtures. It may be concluded that adding of ISSA (generated by incineration of sludge from the wastewater treatment plant Zagreb) within the limits of $10 \%$ does not influence the change of mechanical characteristics.
The paper shows that application of ISSA in production of cement mortar is technologically possible, with regard to the fact that the use of considerable quantity of ISSA (even up to $20 \%$ ) does not deteriorate mortar quality. Quite the contrary, by careful combining of the portion of ISSA and mineral additives it is possible to activate ISSA additionally, and potentially prepare cement mortar of technically competitive properties. Such application would certainly bring additional economic benefits, because on one hand hazardous waste becomes a by-product/raw material, reducing the cost of its management, and on the other hand production of cement mortar becomes more economical and the new product becomes more competitive on the market. 


\section{Acknowledgements}

This work has been fully supported by Croatian Science Foundation under the project "7927 - Reuse of sewage sludge in concrete industry - from infrastructure to innovative construction products". The authors also wish to thank Ivan Brajkovic mag. ing. aedif. for his involvement in the laboratory work.

\section{References}

[1] WYG International Ltd \& WYG savjetovanje d.o.o. \& WYG Ireland \& FCG International Ltd, (2013). Obrada i zbrinjavanje otpada i mulja generiranog pročišćavanjem otpadnih voda na javnim sustavima odvodnje otpadnih voda gradova i općina u hrvatskim županijama, Tehničkoekonomska studija, Projekt zaštite voda od onečišćenja na priobalnom području 2.

[2] Donatello, S.; Cheeseman, C. R., Recycling and recovery routes for incinerated sewage sludge ash (ISSA): A review. // Waste Manage. 33, (2013), pp. 2328-2340. DOl: 10.1016/j.wasman.2013.05.024

[3] EC - DG Environment - B/2, 2001. Disposal and recycling routes for sewage sludge. http://ec.europa.eu/environment/ waste/sludge/pdf/sludge_disposal3.pdf (29.1.2012).

[4] Donatello, S.; Cheeseman, C.; Tyrer, M.; Biggs; A. Sustainable construction products containing sewage sludge ash., Department of Civil and Environmental Engineering, South Kensington campus, Imperial College London, SW7 2AZ. *Akristos Ltd., Innovation Centre 1, Keele University Business Park, Keele, Staffordshire, ST5 5NB, 2004.

[5] Chen, M.; Blanc, D.; Gautier, M.; Mehu, J.; Gourdon, R. Environmental and technical assessments of the potential utilization of sewage sludge ashes (SSAs) as secondary raw materials in construction. // Waste Manage. 33, (2013), pp. 1268-1275. DOI: 10.1016/j.wasman.2013.01.004

[6] Fontes, C. M. A.; Barbosa, M. C.; Toledo Filho, R. D.; Goncalves, J. P. Potentiality of sewage sludge ash as mineral additive in cement mortar and high performance concrete. // Intern. RILEM Confe. on the Use of Recycled Materials in Buildings and Structures, (2004), pp. 797-806.

[7] Monzo, J.; Paya, J.; Borrachero, M. V.; Corcoles, A. Use of sewage sludge ash (SSA) - cement admixtures in mortars. // Cem. Concr. Res. 26, (1996), pp. 1389-1398. DOI: 10.1016/0008-8846(96)00119-6

[8] Monzo, J.; Paya, J.; Borrachero, M. V.; Bellver, A.; PerisMora, E. Study of cement-based mortars containing spanish ground sewage sludge ash. // Stud. Environ. Sci. 71, (1997), pp. 349-354. DOI: 10.1016/S0166-1116(97)80217-8

[9] Monzo, J.; Paya, J.; Borrachero, M. V.; Peris-Mora, E. Mechanical behaviour of mortars containing sewage sludge ash (SSA) and Portland cements with different tricalcium aluminate content. // Cem. Concr. Res. 29, 1(1999), pp 8794. DOI: 10.1016/S0008-8846(98)00177-X

[10] Pan, S. C.; Tseng, D. H.; Lee, C. C.; Lee, C. Use of sewage sludge ash as fine aggregate and pozzolan in Portland cement mortar. // J. Solid Waste Technol. Manage. 28, (2002), pp. 121-130.

[11] Pan, S. C.; Tseng, D. H.; Lee, C. C.; Lee, C. Influence of the fineness of sewage sludge ash on the mortar properties. // Waste Manage. 33, (2003), pp. 1749-1754. DOl: 10.1016/s0008-8846(03)00165-0

[12] Monzo, J.; Paya, J.; Borrachero, M. V.; Girbes, I. Reuse of sewage sludge ashes (SSA) in cement mixtures: the effect of SSA on the workability of cement mortars. // Waste Manage. 23, (2003), pp. 373-381. DOI: 10.1016/S0956053X(03)00034-5

[13] Kokalj, F.; Samec, N.; Juric, B. Utilization of bottom ash from the incineration of separated wastes as a cement substitute. // Waste. Manage. Res. 23, (2005), pp. 468-472. DOI: 10.1177/0734242X05057748

[14] Chen, C. H.; Chiuo, I. J.; Wang, K. S. Sintering effect on cement bonded sewage sludge ash. // Cem. Concr. Compos. 28, (2006), pp. 26-32. DOI: 10.1016/j.cemconcomp.2005.09.003

[15] Cyr, M.; Coutand, M.; Clastres, P. Technological and environmental behaviour of sewage sludge ash (SSA) in cement-based materials. // Cem. Concr. Res. 37, (2007), pp. 1278-1289. DOI: 10.1016/i.cemconres.2007.04.003

[16] Dunster, A. BRE: Incinerated sewage sludge ash (ISSA) in autoclaved aerated concrete (AAC). WRT 177 / WR0115, 2007.

[17] Garces, P.; Perez-Carrion, M.; Garcia-Alcocel, E.; Paya, J.; Monzo, J.; Borrachero, M. V. Mechanical and physical properties of cement blended with sewage sludge ash. // Waste Manage. 28, (2008), pp. 2495-2502. DOI: 10.1016/j.wasman.2008.02.019

[18] Chang, F.; Lin, J.; Tsai, C.; Wang, K. Study on cement mortar and concrete made with sewage sludge ash. // Water Sci. Technol. 62, (2010), pp. 1689-1693. DOI: 10.2166/wst.2010.459

[19] Jamshidi, A.; Mehrdadi, N.; Jamshidi, M. Application of sewage dry sludge as fine aggregate in concrete. // J. Envir. Stud. 37, 59(2011), pp. 4-6.

[20] Liu, J.; Chen, J.; He, Z.; Zhang, G. Study on performance of concrete made from sewage sludge ceramsite. // Open Mat. Scien. J. 5, (2011), pp. 123-129. DOl: $10.2174 / 1874088 \times 01105010123$

[21] Kosior-Kazberuk, M. Application of SSA as Partial Replacement of Aggregate in Concrete. // Polish J. of Environ. 20, 2(2011), pp. 365-370.

[22] Tantawy, M. A.; El-Roudi, A. M.; Abdalla, E. M.; Abdelzaher, M. A. Evaluation of the pozzolanic activity of sewage sludge ash. // ISRN Chemical Engineering. vol. 2012, Aricle ID 487037, 8 pages.

[23] Chen, M.; Blanc, D.; Gautier, M.; Mehu, J.; Gourdon, R. Environmental and technical assessments of the potential utilization of sewage sludge ashes (SSAs) as secondary raw materials in construction. // Waste Manage. 33, (2013), pp. 1268-1275. DOI: 10.1016/j.wasman.2013.01.004

[24] Baeza-Brotons, F.; Garces, P.; Paya, J.; Saval, J. M. Portland cement systems with addition of sewage sludge ash. Application in concretes for the manufacture of blocks. // Journal of Cleaner Production (2014), DOI: 10.1016/ j.clerpo.2014.06.072.

[25] Stasta, P.; Boran, J.; Bebar, L.; Stehlik, P.; Oral, J. Thermal processing of sewage sludge. // Appl. Therm. Eng. 26 , 13(2006), pp. 1420-1426. DOI: 10.1016/j.applthermaleng.2005.05.030

[26] Turovskiy, I. S.; Mathai, P. K. Wastewater sludge processing. John Wiley \& Sons, New Jersey, 2006. DOI: 10.1002/047179161X

[27] Lopes, M. H.; Abelha, P.; Lapa, N.; Oliveira, J. S.; Cabrita, I.; Gulyurtlu, I. The behaviour of ashes and heavy metals during co-combustion of sewage sludges in a fluidised bed. // Waste Manage. 23, (2003), pp. 859-870. DOI: 10.1016/S0956-053X(03)00025-4

[28] Lin, K.; Chang, C. Leaching characteristics of slag from the melting treatment of municipal solid waste incinerator ash. // J. Hazard. Mater. 135, (2006), pp. 296-302. DOI: 10.1016/j.jhazmat.2005.11.064

[29] Donatello, S.; Tyrer, M.; Cheeseman, C. R. Comparison of test methods to assess pozzolanic activity. // Cem. Concr. Compos. 32, (2010), pp. 63-71. DOI: 10.1016/j.cemconcomp.2009.10.008

[30] Mattenberger, H.; Fraissler, G.; Joller, M.; Brunner, T.; Obernberger, I.; Herk, P.; Hermann, L. Sewage sludge ash to phosphorus fertiliser (II): influences of ash and granulate 
type on heavy metal removal. // Waste Manage. 30, (2010), pp. 1622-1633. DOI: 10.1016/j.wasman.2010.03.037

[31] Lin, K. L.; Chiang, K. Y.; Lin, D. F. Effect of heating temperature on the sintering charasteristics of sewage sludge ash. // J. Hazzard. Mater. B128, (2006), pp. 175-181. DOI: 10.1016/j.jhazmat.2005.07.051

[32] Merino I.; Arevalo, L. F.; Romero, F. Characterization and possible uses of ashes from wastewater treatment plants. // Waste Manage. 25, (2005), pp. 1046-1054. DOl: 10.1016/j.wasman.2004.12.023

[33] Coutand, M.; Cyr, M.; Clastres, P. Use of sewage sludge ash as mineral admixture in mortars. // Construction Materials. 159, Issue CM4, (2006), pp. 153-162. DOI: 10.1680/coma.2006.159.4.153

\section{Authors' addresses}

Dražen Vouk, PhD, Assist. Prof.

University of Zagreb,

Faculty of Civil Engineering

Water Research Department,

Kaciceva 26, 10000 Zagreb, Croatia

Email:dvouk@grad.hr

\section{Marijana Serdar, PhD}

University of Zagreb,

Faculty of Civil Engineering,

Department of Materials,

Kaciceva 26, 10000 Zagreb, Croatia

Email: mserdar@grad.hr

Aleksandra Anić Vučinić, PhD, Assist. Prof.

University of Zagreb,

Faculty of Geotechnical Engineering,

Department for Environmental Engineering,

Hallerova aleja 7, 42000 Varaždin, Croatia

Email: aav@gfv.hr 